\title{
Pedagogical Content Knowledge in the Context of Foreign and Second Language Teaching: A Review of the Research Literature
}

\author{
Marie Evens \\ JAN ELEN \\ FIEN DEPAEPE \\ KU Leuven, Belgium
}

Received: 30 September 2015 / Accepted: 8 May 2016

ISSN: $1697-7467$

\begin{abstract}
In this systematic review, 17 articles were analyzed focusing on three research questions: (1) How is pedagogical content knowledge (PCK) conceptualized in empirical research on foreign and second language (FL/L2) education? (2) How is PCK studied in empirical research on FL/L2 education? (3) What are the main conclusions of empirical research on FL/L2 education? An overview of the most important research findings does not reveal generalizable conclusions from research on FL/L2 PCK. The research domain is characterized by a variety of conceptualizations and research methods.
\end{abstract}

Key words: Pedagogical content knowledge, second language, foreign language, teacher knowledge, systematic review.

El conocimiento didáctico del contenido en el dominio de la lengua extranjera y la segunda lengua: una revisión de la literatura científica

RESUMEN: En esta revisión sistemática, se analizaron 17 artículos enfocando tres preguntas de investigación: (a)¿Cómo se conceptualiza el conocimiento didáctico del contenido (CDC) en la investigación empírica de la educación de la lengua extranjera y la segunda lengua (LE/SL)? (b)¿Cómo se estudia el CDC en la investigación empírica de la educación de LE/SL? (c) ¿Cuáles son las principales conclusiones de la investigación empírica de la educación de LE/SL? La revisión de los resultados de investigación más importantes de la investigación de LE/SL CDC no revela conclusiones generalizables. Esta área de investigación es caracterizada por una variedad de conceptualizaciones y de métodos de investigación.

Palabras clave: Conocimiento didáctico del contenido, segunda lengua, lengua extranjera, conocimiento de la enseñanza, revisión sistemática.

\section{INTRODUCTION}

In 1986 Shulman pointed at the unilateral way in which teaching was approached until then. According to Shulman, attention of educational research and teaching practice was either biased towards content, or towards pedagogy. He believed this distinction did not grasp every aspect of teacher knowledge. In reaction to the "missing paradigm" in research and 
practice on teaching, he introduced "pedagogical content knowledge" (PCK): "that special amalgam of content and pedagogy that is uniquely the province of teachers, their own special form of professional understanding" (Shulman, 1987: 8). Shulman (1986) distinguished two main components in PCK: (a) the most regularly taught topics in one's subject area and the most useful forms of representation of these topics, and (b) an understanding of what makes learning of several topics easy or difficult. He considered PCK as one of the seven categories of teacher knowledge, along with content knowledge (CK), general pedagogical knowledge (PK), curriculum knowledge, knowledge of learners, knowledge of educational contexts, and knowledge of educational purposes (Shulman, 1987).

The concept PCK has spread all over the world. It made scholars draw attention to the unique professional experience that is characteristic for teaching, and it allowed to make a distinction between teaching and other professions (Kind, 2009).

Using recently developed instruments to measure teacher cognition (Kleickmann et al., 2013), Shulman's claim was empirically confirmed by several studies in the domain of mathematics, showing that teachers' PCK positively impacts instructional quality and student learning (Baumert et al., 2010; Kunter et al., 2013). Hence, investing in (pre-service) teachers' PCK might improve the quality of education. Baumert et al. (2010) even showed that PCK has a higher correlation with instructional quality than CK. Other studies focused on relationships among different domains in teachers' knowledge base. CK has been shown to be a necessary, though not sufficient, prerequisite for PCK (Baumert et al., 2010; Krauss et al., 2008).

Most research on PCK has focused on sciences and mathematics (Ball, Thames, \& Phelps, 2008; Van Driel \& Verloop, 1998). Multiple review articles are available, such as Depaepe, Verschaffel and Kelchtermans (2013) for mathematics, and Kind (2009), Schneider and Plasman (2011), and van Driel and Verloop (1998) for natural sciences. The focus on exact sciences was not originally intended by Shulman (1986) as he considered PCK to be applicable to different subject matter areas, and initial studies explicitly focused on PCK in various subject domains (e.g., languages (Grossman, 1990), social studies (Gudmundsdottir \& Shulman, 1987) and mathematics (Marks, 1990)). The predominant emphasis on exact sciences could be caused by the high status that society awards to natural sciences and mathematics, causing these domains to be included in national assessments (Grossman \& Stodolsky, 1995). Furthermore, exact sciences are more extensively studied in educational research (van Driel \& Verloop, 1998). This might be explained by the strong linear sequentiality, that makes these domains more delineated (Grossman \& Stodolsky, 1995).

In the domain of foreign (FL) and second languages (L2) ${ }^{1}$, research on PCK is scarce (Atay, Kaslioglu, \& Kurt, 2010; Johnston \& Goettsch, 2000). Nevertheless, PCK is considered as a useful frame of reference for examining the knowledge base of (pre-service) FL/ L2 teachers (Richards, 1998). Johnston and Goettsch (2000) claimed that language teaching is not only a linguistic, but also an educational enterprise, which makes PCK an essential perspective while studying FL/L2 teaching.

1 "Second language learning occurs in an environment where the language is used by the majority of people, whereas foreign language learning occurs in an environment where the language is not a vehicle of ordinary communication.” (Diao, Chandler, \& Sweller, 2007: 297). 
As PCK has been shown to positively impact educational quality (Baumert et al., 2010; Kunter et al., 2013) the domain of FL/L2 would benefit from more research on this topic. The current research base, however, is limited. As a starting point for further research, this study reviews research on PCK in the domain of FL/L2. More specifically, the study investigates how FL/L2 PCK is conceptualized and what can be concluded from research in this domain. The research questions (RQs) are:

RQ1: How is PCK conceptualized in empirical research on FL/L2 education?

RQ2: How is PCK studied in empirical research on FL/L2 education?

RQ3: What are the main conclusions of empirical research on FL/L2 education?

\section{Method}

A systematic review is conducted using three databases (ERIC, WoS, PsycInfo) (Petticrew $\&$ Roberts, 2006). The selected databases include the most high-quality and relevant educational research. The databases were browsed with two combinations of search terms, that is, "pedagogical content knowledge AND second language" and "pedagogical content knowledge AND foreign language", resulting in a total of 346 search hits. Overlapping search results were excluded. The dataset was further reduced using three criteria: (1) All selected articles reported at least one empirical study. (2) The articles focused on PCK. Studies on related but different concepts, for example, "technological pedagogical content knowledge" (Mishra \& Koehler, 2006), and articles only studying PK or CK separately were excluded. (3) All articles focused on FL/L2 teaching. One rater checked whether the abstracts (and if necessary the full texts) met the criteria. In case of doubt, papers were discussed with two other raters until consensus was reached. After applying the criteria only ten articles remained in the sample. Given the small number of articles, the "snowball approach" was used to retrieve additional publications. Reference lists of all potentially relevant articles were inspected on additional relevant articles meeting the inclusion criteria (Doust, Pietrzak, Sanders, \& Glasziou, 2005). As a result, seven articles were added to the dataset, resulting in a total of 17 articles.

Firstly, a within-case analysis was conducted, in which each article was analyzed separately (Miles \& Huberman, 1994). The articles were summarized in a table, consisting of eight categories. The categories "definition" and "components" relate to RQ1. Regarding RQ2, the classification contains four categories: "language and subdomain", "description of participants" (number, teaching experience and educational level), "instruments", and "research questions". The category "main results" belongs to RQ3. Secondly, a cross-case analysis was done (Miles \& Huberman, 1994), in which research-related patterns between the articles were looked for.

\section{RESUlts}

\subsection{RQ1: How is PCK conceptualized in empirical research on FL/L2 education?}

When defining PCK, most studies referred to Shulman $(1986 ; 1987)$, who defined PCK as "that special amalgam of content and pedagogy that is uniquely the province of 
teachers, their own special form of professional understanding" (Shulman, 1987: 8). Only Kissau and Algozzine (2013) used the term PCK without referring to Shulman nor defining PCK. Luo (2004) only referred to Shulman, but did not define PCK. Two articles with the same authors (Meijer, Verloop \& Beijaard, 1999; Meijer, Verloop \& Beijaard, 2002) used the definition of van Driel, Verloop and De Vos (1998), stating that PCK is a specific type of practical knowledge, built by teachers through their experiences in teaching practice and their reflections on these experiences (Fenstermacher, 1994). Walker (2012) used the concept "literacy pedagogical content knowledge" (LPCK), defined as "knowledge about how spoken and written language are structured for learning; recognition that subject areas have their own literacy practices; and capacity to design learning and teaching strategies that take account of subject-specific literacy practices" (Love, 2010: 342). She stated that in language teaching, LPCK and PCK have the same meaning as in this case the subject matter is language.

PCK is composed of several components. Three studies (Meijer et al., 1999; 2002; Wilbur, 2007) mentioned the components originally described by Shulman (1986), that is, knowledge of students' (mis)conceptions and difficulties, and instructional strategies and representations. However, all three studies added at least two components, that is, CK and PK. Meijer et al. (1999; 2002) also added knowledge of context, knowledge of curriculum, and knowledge of purposes for teaching. In contrast to Shulman, the three studies mentioned above (Meijer et al., 1999; 2002; Wilbur, 2007) and Liu (2007) considered CK and PK as components of PCK. Liu (2007) also included knowledge of learners and knowledge of context as PCK components. In these studies, PCK is not considered as one category in teachers' knowledge base, but as an overarching amalgam that consists of several knowledge domains. The majority of the articles in the dataset did not specify PCK components $(n=13)$.

When describing components of PCK, several conceptualizations are used. Liu (2013) built on the distinction made by Fernández-Balboa and Stiehl (1995) in several disciplinary domains, that is, knowledge of subject matter, students, instructional strategies, teaching contexts, and purposes for teaching. However, Liu (2013) did not include the latter component. Meijer et al. (1999; 2002) referred to the work of van Driel et al. (1998) in the domain of natural science when describing PCK components, including knowledge of subject matter, general pedagogy, student learning and conceptions, purposes for teaching, curriculum and media, representations and strategies, and teaching context. Wilbur (2007) used the conceptualization of Feiman-Nemser and Parker (1990) in the domain of math and first language, including the components knowledge of subject matter, academic content from the student's perspective, representing subject matter in appropriate and engaging ways, and organizing students for teaching and learning content.

\subsection{RQ2: How is PCK studied in empirical research on FL/L2 education?}

The reviewed articles were compared with regard to the language(s) and the language subdomain(s) focused on, participants in the studies, research methods used, and major research lines addressed.

Languages and subdomains. The majority of the articles focused on English. One article focused on Spanish (Hlas \& Hildebrandt, 2010), and one on French (van Compernolle \& Henery, 2014). Five articles addressed a combination of languages: Spanish, French and German (Kissau \& Algozzine, 2013; Watzke, 2007); English, Latin, French, German and Dutch 
(Meijer et al., 1999; 2002), and Spanish, French, German, Italian and Portuguese (Wilbur, 2007). Most studies $(n=11)$ focused on language learning in general. Of those that did focus on a subdomain, most chose pragmatics (van Compernolle \& Henery, 2014; Yates \& Wigglesworth, 2005) or a combination of subdomains, that is, reading and literature (Richards et al., 1995), or speaking and writing (Weshah \& Tomok, 2011). Other studies focused on grammar (Johnston \& Goettsch, 2000), L2 acquisition (Gorsuch \& Beglar, 2004), or writing (Hlas \& Hildebrandt, 2010).

Participants (Table 1). Most studies used in-service teachers. Four studies included teachers with different levels of teaching experience. Kissau and Algozzine (2013), Luo (2004) and Richards et al. (1995) included both pre- and in-service teachers. Zhang and Zhan (2014) compared novice teachers with experienced colleagues. Three studies used inservice teachers, but did not specify their teaching experience (van Compernolle \& Henery, 2014; Weshah \& Tomok, 2011; Wilbur, 2007).

Regarding educational levels, most participants were (pre-service) secondary education teachers. Luo (2004) included participants from elementary education only. Participants in Kissau and Algozzine (2013) were recruited from both elementary and secondary education. Atay et al. (2006) did not specify the participants' educational level. The choice for secondary education is logical as in most countries FL/L2 education only starts at the end of primary education (e.g., Flanders) or at the beginning of secondary education (e.g., United States, Watzke, 2007).

In most studies participants were in-service, experienced teachers.

Table 1. Teaching experience and educational level of participants in the reviewed articles

\begin{tabular}{|c|c|c|c|c|c|c|c|}
\hline \multicolumn{2}{|c|}{ Teaching experience } & \multicolumn{6}{|c|}{ Educational level } \\
\hline & & Elementary & Secondary & Higher & Adult & Mixed & Unknown \\
\hline \multicolumn{2}{|c|}{ Pre-service teachers } & & $\begin{array}{l}\text { Hlas \& } \\
\text { Hildebrandt } \\
(2010)\end{array}$ & & & & $\begin{array}{l}\text { Atay et } \\
\text { al. }(2010)\end{array}$ \\
\hline \multirow{4}{*}{$\begin{array}{l}\text { In- } \\
\text { service } \\
\text { teacher }\end{array}$} & $\begin{array}{l}\text { Novice } \\
\text { teachers }\end{array}$ & & $\begin{array}{l}\text { Watzke } \\
(2007)\end{array}$ & & & & \\
\hline & $\begin{array}{l}\text { Experienced } \\
\text { teachers }\end{array}$ & & $\begin{array}{l}\text { Johnston \& } \\
\text { Goettsch } \\
\text { (2000); } \\
\text { Meijer et al. } \\
\text { (1999; 2002) } \\
\text { Walker } \\
(2012)\end{array}$ & $\begin{array}{l}\text { Gorsuch \& } \\
\text { Beglar } \\
\text { (2004); Liu } \\
(2013)\end{array}$ & $\begin{array}{l}\text { Yates \& } \\
\text { Wigglesworth } \\
(2005)\end{array}$ & & \\
\hline & $\begin{array}{l}\text { No } \\
\text { specification }\end{array}$ & & $\begin{array}{l}\text { Weshah \& } \\
\text { Tomok } \\
(2011)\end{array}$ & $\begin{array}{l}\text { van } \\
\text { Compernolle } \\
\text { \& Henery } \\
(2014) ; \\
\text { Wilbur } \\
(2007)\end{array}$ & & & \\
\hline & $\begin{array}{l}\text { Combination } \\
\text { novice and } \\
\text { experienced }\end{array}$ & & & & $\begin{array}{l}\text { Zhang \& Zhan } \\
\text { (2014) }\end{array}$ & & \\
\hline \multicolumn{2}{|c|}{$\begin{array}{l}\text { Combination pre- } \\
\text { service and in-service }\end{array}$} & Luo (2004) & $\begin{array}{l}\text { Richards et } \\
\text { al. (1995) }\end{array}$ & & & $\begin{array}{l}\text { Kissau \& } \\
\text { Algozzine } \\
(2013)\end{array}$ & \\
\hline
\end{tabular}


Research methods (Table 2). Among a variety of methods used to measure PCK, Weshah and Tomok (2011) only used quantitative methods, that is, observations that were coded with a quantitative coding scheme. Most quantitative studies combined quantitative and qualitative methods (mixed methods). The majority of the studies was qualitative. Six different qualitative research instruments were used: (1) document review, for example, of diaries and instructional materials, (2) semi-structured interviews, (3) focus group interviews or group discussions, (4) observations, by an observer in the classroom or by means of video-taped lessons or discussions, (5) performance assessments, in which participants' assignments were analyzed with a qualitative scoring rubric, and (6) qualitatively analyzed surveys. Especially interviews were often used to capture PCK. Most studies using quantitative research methodology included larger datasets than studies following a qualitative research design. Because most studies used qualitative methodology, the average number of participants is rather small.

Table 2

Research methods and analysis techniques that were used to study PCK in the reviewed articles

\begin{tabular}{|c|c|c|c|c|c|c|c|c|c|}
\hline \multirow[t]{2}{*}{ Studies } & \multirow[t]{2}{*}{$\mathrm{N}$} & \multicolumn{2}{|c|}{ Quantitative analysis } & \multicolumn{6}{|c|}{ Qualitative analysis } \\
\hline & & $\begin{array}{l}\vec{D} \\
\vec{D} \\
\vec{n}\end{array}$ & $\begin{array}{l}\text { है } \\
\stackrel{0}{0} \\
\stackrel{0}{0} \\
0 \\
0\end{array}$ & 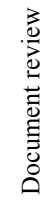 & 总 & 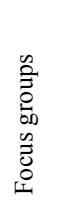 & 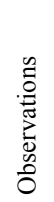 & 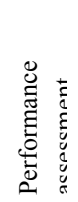 & 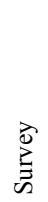 \\
\hline Atay et al. (210) & 18 & & & $\mathrm{X}$ & & $\mathrm{X}$ & & & \\
\hline Gorsuch \& Beglar (2004) & 2 & & & & $\mathrm{X}$ & & & & \\
\hline Hlas \& Hildebrandt (2010) & 18 & & & $\mathrm{X}$ & & & & $\mathrm{x}$ & \\
\hline Johnston \& Goettsch (2000) & 4 & & & & $\mathrm{X}$ & & $\mathrm{X}$ & & \\
\hline Kissau \& Algozzine (2013) & 44 & $\mathrm{X}$ & & & $\mathrm{x}$ & & & & \\
\hline Liu (2013) & 1 & & & $\mathrm{X}$ & $\mathrm{X}$ & & $\mathrm{X}$ & & \\
\hline Luo (2004) & 8 & & & $\mathrm{X}$ & $\mathrm{x}$ & & & & \\
\hline Meijer et al. $(1999 ; 2002)$ & 13 & & & & $\mathrm{X}$ & & & $\mathrm{X}$ & \\
\hline Richards et al. (1995) & 20 & $\mathrm{X}$ & & & $\mathrm{X}$ & & & $\mathrm{X}$ & \\
\hline van Compernolle \& Henery (2014) & 1 & & & & & & $\mathrm{x}$ & & \\
\hline Walker (2012) & 6 & & & & & & $\mathrm{X}$ & & \\
\hline Watzke (2007) & 9 & & & $\mathrm{X}$ & & $\mathrm{X}$ & $\mathrm{X}$ & & \\
\hline Weshah \& Tomok (2011) & 30 & & $\mathrm{X}$ & & & & & & \\
\hline Wilbur (2007) & 32 & $\mathrm{X}$ & & $\mathrm{X}$ & & & & & $\mathrm{X}$ \\
\hline Yates \& Wigglesworth (2005) & 84 & $\mathrm{X}$ & & & $\mathrm{X}$ & $\mathrm{X}$ & & & \\
\hline
\end{tabular}

Major research lines. Two major research lines can be identified in the articles; (1) studies on the nature of PCK, and (2) studies on its development. Each research line is divided in two subgroups. In the first research line a distinction is made between (1.1) studies focusing on the influence of teachers' characteristics (e.g., teaching experience, teaching qualifications) on PCK, and (1.2) studies describing PCK without focusing on specific background characteristics. In the second research line a distinction is made between (2.1) intervention 
and (2.2) ascertaining studies. Intervention studies examine the effects of a specific educational intervention on (pre-service) teachers' PCK, while ascertaining studies describe the development of teachers' PCK during a particular timespan (e.g., their teaching training or career). Table 3 gives an overview of the research lines and their subgroups. Some studies can be positioned in multiple cells because they addressed several research questions. Most studies belong to research line 1, focusing on the nature of PCK.

Table 3

Major research lines that are central to the reviewed studies

\begin{tabular}{|c|c|c|}
\hline Research line & Subdivision & Studies \\
\hline $\begin{array}{l}\text { (1) Nature of } \\
\text { PCK }\end{array}$ & $\begin{array}{l}\text { (1.1) Studying the influence } \\
\text { of teacher characteristics }\end{array}$ & $\begin{array}{l}\text { Hlas \& Hildebrandt (2010); Kissau \& Algozzine (2013); Luo } \\
\text { (2004); Meijer et al. (1999); Richards et al. (1995) }\end{array}$ \\
\hline & (1.2) Description of PCK & $\begin{array}{l}\text { Gorsuch \& Beglar (2004); Johnston \& Goettsch (2000); Liu } \\
\text { (2013); Meijer et al. (1999; 2002); Watzke (2007); Wilbur } \\
\text { (2007); Zhang \& Zhan (2014) }\end{array}$ \\
\hline $\begin{array}{l}\text { (2) Development } \\
\text { of PCK }\end{array}$ & $\begin{array}{l}\text { (2.1) Ascertaining study } \\
\text { (2.2) Intervention study }\end{array}$ & $\begin{array}{l}\text { Liu (2013); Watzke (2007); Wilbur (2007) } \\
\text { Atay et al. (2010); van Compernolle \& Henery (2014); Weshah } \\
\text { \& Tomok (2011); Yates \& Wigglesworth (2005) }\end{array}$ \\
\hline
\end{tabular}

\subsection{RQ3: What are the main conclusions of empirical research on FL/L2 education?}

The results are presented per research line. Research line 1 pertains to the nature of PCK. Most studies in this research line belong to subgroup 1.1, focusing on the influence of teachers' characteristics on PCK. Teaching experience and teaching qualifications are the teacher characteristics studied. Firstly, as established by studies on teaching experience, PCK of experienced and novice teachers seems to differ. Richards et al. (1995) found that experienced teachers possessed better PCK than novice teachers. For instance, they showed a different mindset towards the use of literary texts; novice teachers saw texts as a means for language skills development, while experienced teachers considered the experience of reading a particular text as a valuable process. According to Luo (2004), PCK had a different source in both groups. Experienced teachers indicated they mostly gained PCK from practical experience, while novice teachers reported to have acquired PCK in teacher education. Secondly, studies examining the influence of teaching qualifications on PCK conclude that (pre-service) teachers with teaching qualifications have better PCK than teachers without teaching qualifications (Kissau \& Algozzine, 2013), or than students with other qualifications, for example, literary arts (Hlas \& Hildebrandt, 2010). Meijer et al. (1999) did not speak in terms of better or worse PCK, but found that teachers with more formal teacher training (the younger teachers taking part in the study) showed more similarities in their practical knowledge than teachers with little formal training (the older participants).

Studies in subgroup 1.2 are descriptive in nature. Most of these studies described participants' PCK (Gorsuch \& Beglar, 2004; Meijer, 1999; 2002; Zhang \& Zhan, 2014). Gorsuch and Beglar (2004) provided case-studies with detailed description of two teachers' PCK. Meijer et al. (1999; 2002) described their participants' practical knowledge, of which PCK is part, and classified their participants in one of three profiles of practical knowledge: (1) 
practical knowledge focusing on subject matter knowledge, (2) practical knowledge focusing on student knowledge (general knowledge on students of a specific age, that is not specifically related to language learning), and (3) practical knowledge focusing on knowledge of student learning and understanding. Zhang and Zhan (2014) described the knowledge base of nonnative English-speaking teachers of English as a L2. These teachers were especially strong in grammar and language structures, and in the ability to make English more understandable and accessible to students, while they were challenged by the contextual differences between the Canadian education system and the system in their home country. Two studies aimed at empirically refining the concept PCK (Johnston \& Goettsch, 2000; Liu, 2013). Interviewing and observing four experienced teachers, Johnston and Goettsch (2000) concluded that teachers' knowledge base of language teaching consists of CK, PCK and knowledge of learners, and that these components are intertwined in a complex way. Liu (2013) aimed at finding out which component of PCK is most active (whether teachers' PCK is dominated by knowledge on the English language or by general teaching skills), and concluded that in comparison to all other components PK has the largest influence on PCK.

In the second research line, focusing on the development of $\mathrm{PCK}^{2}$, ascertaining and intervention studies are distinguished. Firstly, the sample contains three ascertaining studies (2.1). Watzke (2007) found in a longitudinal study that, as teachers became more experienced, they developed contemporary approaches in FL pedagogy. He described this development in four core categories (influence of prior knowledge on instructional decisions, attitudes towards teacher control, instructional goals for language teaching, and responses to student affect). For instance, concerning the influence of teachers' prior knowledge on their teaching practice, participants shifted from relying on their prior knowledge as a learner to mainly relying on their prior knowledge as a teacher. According to the single-case study of Liu (2013), the critical phase for teachers of English as a L2 to develop PCK is the induction phase, that is, their first years as a teacher, because in this early period novice teachers make the transition from student to teacher and they can immediately apply in class what they learned during teacher education. Wilbur (2007) did not study the PCK development of (pre-service) teachers, but gave an overview of the role PCK played in 32 teacher education institutions in the United States. She highlighted the variety in ways in which teacher education is organized (dependent on varied instructor beliefs about teaching) and observed that most pre-service teachers did not leave their teacher education equipped with the PCK needed to cope with diverse learners.

A second subset consists of intervention studies (2.2). Most intervention studies reported a positive impact of their intervention on participants' PCK development (Atay et al., 2010; van Compernolle \& Henery, 2014; Weshah \& Tomok, 2011; Yates \& Wigglesworth, 2005). The intervention of Atay et al. (2010) consisted of an experiential task for pre-service teachers, focusing on the design and presentation of interactive activities about a novel. The participants took part in several micro-teaching sessions and received feedback from their instructor and peers afterwards. Especially the feedback process was found to be beneficial for PCK development, a finding similar to van Compernolle and Henery (2014). In the latter

${ }^{2}$ These studies are different from the studies focusing on the effect of teaching experience on PCK (subgroup 1.1). The studies in subgroup 1.1 compared groups (based on teaching experience) with each other. The studies in subgroup 2.1 tracked the development of one or more teachers' PCK in a longitudinal design. 
intervention an instructor explored content-based pragmatics instruction, which is a Vygotskian approach to L2 pragmatics teaching. Especially the mediation by an expert mentor seemed to impact PCK development. Yates and Wigglesworth (2005) organized several workshops, but only found small gains in PCK after the workshops. In this study some teachers were involved in the development of the intervention. The authors also studied the effect of this involvement on teachers' PCK, and found large gains in PCK. They attributed this finding to the longer duration of this phase in comparison with the intervention itself, and hence the possibility for researchers to develop more profound contact with the participants. Weshah and Tomok (2011) found a positive influence on PCK of a training program consisting of several courses about how to teach FL/L2. However, these authors did not describe their intervention thoroughly and did not elaborate on especially effective parts of their intervention. Not all intervention studies showed positive results. In Walker (2012) only two out of six participants showed gains in LPCK after an intervention, consisting of a three-day course on practicum assessment. The results might be caused by, amongst others, the participants adhering to their own paradigm of language learning, the high intellectual demand of the performance tasks in the intervention, and the many weaknesses of the course with regard to its nature, pedagogy and content.

\section{Discussion AND CONClusions}

This study reviewed empirical research about PCK in the context of FL/L2. Based on a search in three databases (ERIC, WoS, PsycInfo) and a search via the snowball approach, 17 articles were analyzed according to three RQs: (1) How is PCK conceptualized in empirical research on FL/L2 education? (2) How is PCK studied in empirical research on FL/L2 education? (3) What are the main conclusions of empirical research on FL/L2 education?

Regarding RQ1, researchers clearly do not agree on the conceptualization of PCK in the context of FL/L2. Although most studies used Shulman's definition of PCK, there is no consensus on the components of PCK. While most studies do not describe components of PCK, the others disagree on their conceptualizations. This lack of consensus mirrors the findings of Depaepe et al. (2013), who reviewed research on PCK in mathematics education, and Kind (2009), who reviewed studies in natural science PCK.

Concerning RQ2, addressing how PCK is studied in the FL/L2 context, three conclusions can be drawn, which are not entirely similar to the conclusions in the exact sciences. Firstly, research on PCK in the FL/L2 context is scarce. Only 17 articles met the inclusion criteria. In contrast, using even more restrictive inclusion criteria, Depaepe et al. (2013) could review 60 articles focusing on PCK in the context of mathematics. Moreover, Schneider and Plasman (2011) retrieved 91 articles in the domain of science PCK. The higher societal status of exact sciences (Grossman \& Stodolsky, 1995) or their more delineated nature (van Driel \& Verloop, 1998) might be plausible reasons. Another reason might be terminological confusion. Many terms are used as synonyms for PCK in the FL/L2 context, such as "knowledge about language" (Borg, 2001), "knowledge of grammar-specific methodological strategies" (Hadjioannou \& Hutchinson, 2010), or "teacher language awareness" (Andrews \& McNeill, 2005). Secondly, a variety of methods and research designs is used. This conclusion is similar in the field of mathematics and natural sciences (Depaepe et al., 2013; van Driel \& 
Verloop, 1998). There is no consensus on instruments that are effective in measuring PCK. Especially instruments that allow to measure PCK on a large scale are lacking. Thirdly, the reviewed studies addressed only two research lines, that is, the nature and the development of PCK. Again, it seems that research on PCK in mathematics and natural sciences is richer and even more diverse, also covering studies on the relation between teachers' CK and their PCK, between teachers' PCK and their teaching behavior, and between teachers' PCK and student learning outcomes (Depaepe et al., 2013; Kind, 2009; Schneider \& Plasman, 2011; van Driel \& Verloop, 1998).

RQ3 pertained to the most important findings in the domain of FL/L2 PCK. Within the research line on the nature of PCK, a first group of studies focused on the influence of teacher characteristics on PCK. Both teaching experience and teacher education seem to impact PCK. Richards et al. (1995) showed a positive effect of teaching experience on PCK. These findings are similar to the findings of the ascertaining studies on PCK development (group 1.2), showing that PCK develops as teachers gain more experience, and reflect on their experiences (Watzke, 2007), and that this development especially happens in the first years as a teacher (Liu, 2013). These results correspond to results in the mathematics (Lee, 2010; Lim-Teo et al., 2007) and the natural science domain (Clermont et al., 1993; 1994) about the importance of teaching experience for PCK development. The importance of reflection on teaching practice for the development of PCK has also been shown in the review of intervention studies of Evens, Elen and Depaepe (2015). Teaching qualifications are another influential teacher characteristic. Participants with teaching qualifications showed better PCK than teachers without qualifications or students with other qualifications (Hlas \& Hildebrandt, 2010; Kissau \& Algozzine, 2013), a finding that also applies to the mathematics domain (Krauss et al., 2008). A second group of studies within research line 1 (on the nature of PCK) consisted of case-studies that described the knowledge base of (in most cases) a small number of participants. These results can hardly be generalized to a larger population.

The second research line (on the development of PCK) mainly consisted of intervention studies. Almost all interventions were effective in promoting PCK development. Most of these studies did not use a pre-test nor a control group, and did not seem to be the result of a systematic design process, which makes it difficult to discuss causalities. However, some conclusions can be drawn. Firstly, in Atay et al. (2010) and van Compernolle and Henery (2014) especially expert feedback on participants' practice was beneficial. This result corresponds with Nilssen (2010), who showed the importance of mentoring for PCK development. The importance of the help of an expert facilitator for PCK development was also shown in the review of Evens et al. (2015). Secondly, Yates and Wigglesworth (2005) found that it was especially beneficial for their participants' PCK development to take part in the development of a course on PCK. These authors highlighted the positive effect of profound contacts between researchers and participants. This finding matches the result of Evens et al. (2015) that contact with colleagues is beneficial for PCK development, along with explicitly introducing the concept PCK to teachers, which happened in the development phase of the intervention of Yates and Wigglesworth (2005).

After reviewing research in the domain of FL/L2 PCK, the question remains whether research findings on PCK can be generalized across domains. As there is only a small amount of research conducted in the context of FL/L2 so far, and as there is only little consensus concerning the conceptualization of PCK in the context of FL/L2, the field needs 
more research and theory development before straightforward conclusions can be drawn. Furthermore, as PCK is important for educational quality (Baumert et al., 2010; Kunter et al., 2013), the research field would benefit from conducting more research on PCK, according to the following guidelines. Firstly, a common conceptual framework is needed to describe PCK in the context of FL/L2. Authors should be clear on how they define PCK and its components. A clear conceptualization is beneficial for relating several research findings to each other, and for the development of measurement instruments. Secondly, as FL/L2 PCK has mainly been studied on small samples, future research could include larger datasets and develop validated instruments that allow to measure FL/L2 PCK in these datasets, in order to generate conclusions that are generalizable to a larger population. Furthermore, it is recommended to use several research instruments (and mixed methods) as this leads to richer results. Thirdly, intervention studies have until now mainly been based on ad hoc interventions, rarely with a clear vision on what PCK exactly comprises or how it should be operationalized. Hence, further research is needed in which the design of interventions starts from evidence based instructional design principles and a clear operationalization of PCK. In order to exactly find out the contribution of the intervention to teachers' knowledge, these intervention studies should include a pre- and a post-test, and compare at least one experimental group with a control group. As appears from the reviewed intervention studies, especially mentoring experiences and profound contact between researchers and teachers seem to be beneficial for PCK development. Therefore, it would be interesting for future research to systematically study the effect of interventions incorporating these elements. Fourthly, a challenge for further research is to focus on a broader range of research questions, such as the relation between FL/L2 PCK and educational quality and learning outcomes, the relation between different knowledge domains, or the influence of a broader range of teacher characteristics on PCK.

\section{REFERENCES}

Andrews, S., and McNeill, A. (2005). "Knowledge about language and the 'good language teacher"”, in N. Bartels (Ed.), Applied linguistics and language teacher education (pp. 159 -178). New York: Springer.

Atay, D., Kaslioglu, O., and Kurt, G. (2010). "The pedagogical content knowledge development of prospective teachers through an experiential task", Procedia Social and Behavioral Sciences, 2: 1421-1425.

Ball, D.L., Thames, M.H., and Phelps, G. (2008). "Content knowledge for teaching: What makes it special?", in Journal of Teacher Education, 59: 389-407.

Baumert, J., Kunter, M., Blum, W., Brunner, M., Voss, T., Jordan, A., Klussman, U., Krauss, S., Neubrand, M., and Tsai, Y. (2010). "Teachers' mathematical knowledge, cognitive activation in the classroom, and student progress", in American Educational Research Journal, 47, 133-180.

Borg, S. (2001). "Self-perception and practice in teaching grammar", in ELT Journal, 55: 21-29.

Clermont, C.P., Krajcik, J.S., and Borko, H. (1993). "The influence of an intensive in-service workshop on pedagogical content knowledge growth among novice chemical demonstrators", in Journal of Research in Science Teaching, 30: 21-43. 
Clermont, C.P., Borko, H., and Krajcik, J.S. (1994). "Comparative study of the pedagogical content knowledge of experienced and novice chemical demonstrators", in Journal of Research in Science Teaching, 31: 419-441.

Depaepe, F., Verschaffel, L., and Kelchtermans, G. (2013). "Pedagogical content knowledge: A systematic review of the way in which the concept has pervaded mathematics educational research" in Teaching and Teacher Education, 34: 12-25.

Diao, Y., Chandler, P., and Sweller, J. (2007). "The effect of written text on comprehension of spoken English as a foreign language" in American Journal of Psychology, 120: 237-261.

Doust, J.A., Pietrzak, E., Sanders, S., and Glasziou, P.P. (2005). "Identifying studies for systematic reviews of diagnostic tests was difficult due to the poor sensitivity and precision of methodologic filters and the lack of information in the abstract", in Journal of Clinical Epidemiology, 58: 444-449.

Evens, M., Elen, J., Depaepe, F. (2015). "Developing pedagogical content knowledge: Lessons learned from intervention studies", in Education Research International, 2015, art.nr. 790417.

Feiman-Nemser, S., and Parker, M.B. (1990). "Making subject matter part of the conversation in learning to teach", in Journal of Teacher Education, 41(3): 32-43.

Fenstermacher, G.D. (1994). "The knower and known: The nature of knowledge in research on teaching", in Review of Research on Teaching, 20: 3-56.

Fernandez-Balboa, J., and Stiehl, J. (1995). "The generic nature of pedagogical content knowledge among college professors", in Teaching and Teacher Education, 11(3): 293-306.

Gorsuch, G.J., and Beglar, D. (2004). "Teaching second language acquisition courses: Views from new faculty", in TESL-EJ, 8. Retrieved from http://www.tesl-ej.org/wordpress/issues/ volume8/ej29/ej29a2/

Grossman, P.L. (1990). The making of a teacher: Teacher knowledge and teacher education. New York: Teachers College Press.

Grossman, P.L., and Stodolsky, S. (1995). "Content as context: The role of school subjects in secondary school teaching", in Educational Researcher, 24: 5-11.

Gudmundsdottir, S., and Shulman, L. (1987). "Pedagogical content knowledge in social studies", in Scandinavian Journal of Educational Research 31: 59-70.

Hadjioannou, X., and Hutchinson, M. C. (2010). "Putting the G back in English: Preparing preservice teachers to teach grammar", in English Teaching: Practice and Critique, 9: 90-105.

Hlas, A., and Hildebrandt, S. (2010). "Demonstrations of pedagogical content knowledge: Spanish Liberal Arts and Spanish Education majors" writing", in L2 Journal, 2: 1-22.

Johnston, B., and Goettsch, K. (2000). "In search of the knowledge base of language teaching: Explanations by experienced teachers", in The Canadian Modern Language Review, 56: 437-468.

Kind, V. (2009). "Pedagogical content knowledge in science education: Perspectives and potential for progress", in Studies in Science Education, 45: 169-204.

Kissau, S.P., and Algozzine, B. (2013)."Foreign language student teaching: Do supervisor qualifications really matter?" in Foreign Language Annals, 46: 175-190.

Kleickmann, T., Richter, D., Kunter, M., Elsner, J., Besser, M., Krauss, S., and Baumert, J. (2013). "Teachers' content knowledge and pedagogical content knowledge: The role of structural differences in teacher education" in Journal of Teacher Education, 64: 90-106.

Krauss, S., Brunner, M., Kunter, M., Baumert, J., Blum, W., Neubrand, M., and Jordan, A. (2008). "Pedagogical content knowledge and content knowledge of secondary mathematics teachers" in Journal of Educational Psychology, 100: 716-725.

Kunter, M., Klusmann, U., Baumert, J., Richter, D., Voss, T., and Hachfeld, A. (2013)."Professional competence of teachers: Effects on instructional quality and student development", in Journal of Educational Psychology, 105(3): 805-820. 
Lee, J. (2010). “Exploring kindergarten teachers' pedagogical content knowledge of mathematics”, in International Journal of Early Childhood, 42: 27-41.

Lim-Teo, S.K., Chua, K.G., and Cheang, W.K. (2007). "The development of diploma in education student teachers' mathematics pedagogical content knowledge", in International Journal of Science and Mathematics Education, 5: 237-261.

Liu, S. (2013). "Pedagogical content knowledge: A case study of ESL teacher educator", in English Language Teaching, 6: 128-138.

Love, K. (2010). "Literacy pedagogical content knowledge in the secondary curriculum", in Pedagogies: An International Journal, 5(4): 338-355.

Luo, W. (2004). "Construction of teacher knowledge: Learning to teach EFL at the elementary level”, in 國立新竹師範學院語文學報, 12: 259-286.

Marks, R. (1990). "Pedagogical content knowledge: From a mathematical case to a modified conception", in Journal of Teacher Education, 41: 3-11.

Meijer, P.C., Verloop, N., and Beijaard, D. (1999). "Exploring language teachers' practical knowledge about teaching reading comprehension", in Teaching and Teacher Education, 15: 59-84.

Meijer, P.C., Verloop, N., and Beijaard, D. (2002). "Multi-method triangulation in a qualitative study on teachers' practical knowledge: An attempt to increase internal validity", in Quality and Quantity, 36: 145-167.

Miles, M.B., and Huberman, A.M. (1994). Qualitative data analysis (2nd ed.). Thousand Oaks: Sage.

Mishra, P., and Koehler, M.J. (2006). "Technological pedagogical content knowledge: A new framework for teacher knowledge", in Teachers College Record, 108: 1017-1054.

Nilssen, V.L. (2010). "Guided planning in first-year student teachers' teaching", in Scandinavian Journal of Educational Research, 54: 431-449.

Petticrew, M., and Roberts, H. (2006). Systematic reviews in the social sciences: A practical guide. Oxford: Blackwell Publishing.

Richards, J.C., Li, B., and Tang, A. (1995). " A comparison of pedagogical reasoning skills in novice and experienced Esl teachers", in RELC Journal, 26(1).

Richards, J. (1998). Beyond training. Cambridge: Cambridge University Press.

Schneider, R.M., and Plasman, K. (2011). "Science Teacher Learning Progressions: A review of science teachers' pedagogical content knowledge development", in Review of Educational Research, 81: 530-565.

Shulman, L.S. (1986). "Those who understand: Knowledge growth in teaching", in Educational Researcher, 15: 4-14.

Shulman, L.S. (1987). "Knowledge and teaching: Foundations of the new reform", in Harvard Educational Review, 57(1): 1-22.

van Compernolle, R.A., and Henery, A. (2014). "Learning to do conceptbased pragmatics instruction: Teacher development and L2 pedagogical content knowledge", in Language Teaching Research: 1-23.

van Driel, J., and Verloop, N. (1998). “'Pedagogical content knowledge': een verbindend element in de kennisbasis van docenten ['Pedagogical content knowledge': A unifying element in the knowledge base of teachers]", in Pedagogische Studiën, 75: 225-237.

van Driel, J.H., Verloop, N., and de Vos, W. (1998). "Developing science teachers' pedagogical content knowledge", in Journal of Research in Science Teaching, 35(6): 673-695.

Walker, E. (2012). "Literacy-oriented pedagogy in the advice of experienced language teachers as prospective practicum assessors", in Pedagogies: An International Journal, 7: 182-198.

Watzke, J.L. (2007). "Foreign language pedagogical knowledge: Toward a developmental theory of beginning teacher practices", The Modern Language Journal, 91: 63-82. 
Weshah, H.A., and Tomok, T.N. (2011). "The impact of a training program based on pedagogical knowledge on improving the speaking and writing skills teaching practices of female English language teachers", in Reading Improvement, 48: 179-194.

Wilbur, M.L. (2007). "How foreign language teachers get taught: Methods of teaching the methods course", in Foreign Language Annals, 40(1), 79-101.

Yates, L., and Wigglesworth, G. (2005). "Researching the effectiveness of professional development in pragmatics", in N. Bartels (Ed.), Applied linguistics and language teacher education (pp. 261-280). New York: Springer.

Zhang, F., and Zhan, J. (2014). "The knowledge base of non-native English-speaking teachers: perspectives of teachers and administrators", in Language and Education, 28: 568-582. 